\title{
Anaerobic slurry co-digestion of poultry manure and straw: effect of organic loading and temperature
}

\author{
Azadeh Babaee ${ }^{1}$, Jalal Shayegan ${ }^{1 *}$ and Anis Roshani ${ }^{2}$
}

\begin{abstract}
In order to obtain basic design criteria for anaerobic digestion of a mixture of poultry manure and wheat straw, the effects of different temperatures and organic loading rates on the biogas yield and methane contents were evaluated. Since poultry manure is a poor substrate, in term of the availability of the nutrients, external supplementation of carbon has to be regularly performed, in order to achieve a stable and efficient process. The complete-mix, pilot-scale digester with working volume of $70 \mathrm{~L}$ was used. The digestion operated at $25^{\circ} \mathrm{C}, 30^{\circ} \mathrm{C}$ and $35^{\circ} \mathrm{C}$ with organic loading rates of 1.0, 2.0, 2.5, 3.0, 3.5 and $4.0 \mathrm{~kg}$ Volatile solid $/ \mathrm{m}^{3} \mathrm{~d}$ and a HRT of 15 days. At a temperature of $35^{\circ} \mathrm{C}$, the methane yield was increased by $43 \%$ compared to $25^{\circ} \mathrm{C}$. Anaerobic co-digestion appeared feasible with a loading rate of $3.0 \mathrm{~kg} \mathrm{VS} / \mathrm{m}^{3} \mathrm{~d}$ at $35^{\circ} \mathrm{C}$. At this state, the specific methane yield was calculated about $0.12 \mathrm{~m}^{3} / \mathrm{kg}$ VS with a methane content of $53-70.2 \%$ in the biogas. The volatile solid (VS) removal was $72 \%$. As a result of volatile fatty acid accumulation and decrease in $\mathrm{pH}$, when the loading rate was less than 1 or greater than $4 \mathrm{~kg} \mathrm{VS} / \mathrm{m}^{3} \mathrm{~d}$, the process was inhibited or overloaded, respectively. Both the lower and higher loading rates resulted in a decline in the methane yield.
\end{abstract}

Keywords: Anaerobic digestion, Poultry manure, Wheat straw, Biogas, Yield

\section{Introduction}

In the past few decades, the large amounts of animal manure and slurries have been produced by the animal breeding sector as well as the wet organic waste streams represent a constant pollution risk with a potential negative impact on the environmental, if not managed optimally. When untreated or poorly managed, animal manure becomes a major source of air and water pollution. Nutrient leaching, mainly nitrogen, phosphorus and ammonia evaporation and pathogen contamination are some of the major threats [1]. The animal production sector is responsible for $18 \%$ of the overall greenhouse gas emissions, measured in $\mathrm{CO}_{2}$ equivalent and for $37 \%$ of the anthropogenic methane, which has 23 times the global warming potential of $\mathrm{CO}_{2}$ [2]. Annually, approximately 400 million tons of wastes have been produced by Iran livestock industry (cattle and poultry) and agriculture sector. It means that it really needs an integrated waste management.

\footnotetext{
* Correspondence: shayegan@sharif.edu

'University of Sharif, Tehran, Iran

Full list of author information is available at the end of the article
}

Anaerobic co-digestion of organic matters results in waste stabilization as well as in biogas production. This gas usually contains more than $50 \%$ methane, and therefore it can be used as bio-fuel in power generation systems to produce heat and energy [3]. Wastes have been effectively used as biogas materials by various studies [4]. The other Benefits of the anaerobic digestion of animal manure are pathogen reduction through sanitation, improved fertilization efficiency, less nuisance from odors and flies and etc. [5]. Anaerobic digestion reduces the majority of pathogenic agents, if can be carried out under mesophilic or thermophilic conditions [6].

The anaerobic digestion of organic material is a complex process, involving a number of different degradation steps. The microorganisms that participate in the process may be specific for each degradation step and thus could have different environmental requirements such as temperature, $\mathrm{pH}$, moisture, carbon source, nitrogen and $\mathrm{C} / \mathrm{N}$ ratio. Many researchers have reported significant effects of temperature on the microbial community, process kinetics and stability and methane yield.

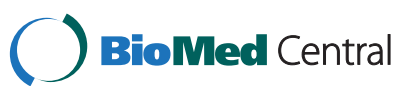


Lower temperatures during the process are known to decrease microbial growth, substrate utilization rates, and biogas production. Moreover, lower temperatures may also result in an exhaustion of cell energy, a leakage of intracellular substances or complete lysis. In contrast, high temperatures lower biogas yield due to the production of volatile gases such as ammonia which suppresses methanogenic activities [7].

Animal waste often has very high total ammonia nitrogen concentrations due to presence of ammonia as well as protein and urea [8]. Nitrogen is an essential nutrient for anaerobic organisms [9], consequently, the inhibitory effects of ammonia, as far as is known, influence mainly the phase of methanogenesis in anaerobic reactors [10], released from decomposition of organic ammonia. It has been suggested that poultry manure is best treated with other wastes because of its high nitrogen content [11]. Crop residues represent another fraction of agricultural waste. Substantial quantities of unused stalks, straws and bark are produced from a variety of crops, which could be used for energy generation, but they are poor substrate in term of nitrogen and phosphate. Therefore, co-digestion of animal manure and crop residues can supply a proper $\mathrm{C} / \mathrm{N}$ ratio for microorganisms. This ratio is the balance of food that a microbe requires in order to grow. The optimal $\mathrm{C} / \mathrm{N}$ ratio is $20-30$ and excess $\mathrm{N}$ can lead to ammonia inhibition of digestion [12]. The unbalanced nutrients are regarded as an important factor limiting anaerobic digestion of organic wastes. For the improvement of nutrition and $\mathrm{C} / \mathrm{N}$ ratios, codigestion of organic mixtures is employed.

In spite of high production of poultry manure, anaerobic digestion of this kind of organic waste has not been studied as much as cow and swine manure. Cow manure is a cellulose-rich component that high amount of cellulose and hemi- cellulose cause suitable $\mathrm{C} / \mathrm{N}$ ratio and therefore it can be digested easily in anaerobic conditions. It is also a good fertilizer as it will not burn the plants. Inversely, poultry manure is an ammonia-rich component which cannot be used as a fertilizer because it will burn the plants as a result of high ammonia content. In order to obtain suitable $\mathrm{C} / \mathrm{N}$ ratio, co-digestion of poultry manure has been done with hog manure, swine manure, fruit and vegetable wastes [13]. Co-digestion can utilize the nutrients and bacterial diversities in various wastes to optimize the digestion process. Co-digestion of poultry manure with wheat straw that has been done in this study may be considered as a new issue and the objective of the study is finding the optimum temperature and loading rate in a pilot-scale reactor that will be discussed fully below.

\section{Material and methods Waste characteristics}

The poultry waste and straw were obtained from a local farm in Tehran and stored at $4^{\circ} \mathrm{C}$. Poultry manure and straw were mixed together, straw with portion of $80 \%$ by weight and Poultry manure $20 \%$ by weight in order to supply a proper $\mathrm{C} / \mathrm{N}$ ratio $(\mathrm{C} / \mathrm{N} \approx 23)$. The waste mixture consist of $90 \%$ total solid (TS) and $80 \%$ of TS was Volatile Solid. The other characteristics of waste are presented in Table 1. Components of the obtained samples were determined by the procedures described in the Standard Methods [14].

\section{Experimental set-up}

A cylindrical CSTR reactor with a working volume of 60 $\mathrm{L}$ (total digester volume $70 \mathrm{~L}$ ) was operated at a $15 \mathrm{~d}$ HRT for all runs. The reactor was fitted with a top plate, which supported the mixer, mixer motor and gas sampler. Sampling valves were located at positions corresponding to the top, middle and bottom layer of digester contents. The reactor had one outlet at the bottom for effluent removal. The contents of the reactor were mixed as controlled by a timer, which was activated for 30 min every hour. It was operated at $35^{\circ} \mathrm{C}$ and then was obtained at $30^{\circ} \mathrm{C}$ and $25^{\circ} \mathrm{C}$.

\section{Reactor operation}

First, $40 \mathrm{~L}$ of anaerobic sludge from a dairy factory and $20 \mathrm{~L}$ water were transferred to the reactor. Daily feeding was commenced approximately 24 days after start-up. Raw waste characteristics over the study period are given in Table 1 . The digestion operated at $25^{\circ} \mathrm{C}, 30^{\circ} \mathrm{C}$ and $35^{\circ} \mathrm{C}$ with organic loading rates of 1.0, 2.0, 2.5, 3.0, 3.5 and $4.0 \mathrm{~kg} \mathrm{VS} / \mathrm{m}^{3} \mathrm{~d}$. For preventing accumulation, because of daily feeding, 4 liters of content was removed every day. It was calculated according to HRT of 15 days. It is worth mentioning that gradual hydrolysis of cellulose caused the high amount of COD accumulation.

\section{Analytical methods}

The produced biogas was measured daily by water displacement method and its composition was measured by gas chromatograph. Total solids (TS), volatile solids (VS), $\mathrm{pH}$ and alkalinity were determined according to the APHA Standard Methods [14]. Total nitrogen (TN) was estimated by the Kjeldahl method [14].

\section{Table 1 Characteristics of the feed solids as sampled}

\begin{tabular}{lcc}
\hline Parameters & Poultry manure & Straw \\
\hline Ammonia nitrogen (w/w \%) & 5.65 & 0.61 \\
Total Nitrogen (w/w \%) & 5.67 & 0.63 \\
$\mathrm{COD}(\mathrm{w} / \mathrm{w} \%)$ & 35.88 & 51.88 \\
$\mathrm{C} / \mathrm{N}$ ratio & 6.35 & 84.22 \\
$\mathrm{pH}$ & 7.3 & - \\
\hline
\end{tabular}




\section{Result}

Effect of temperatures and feed loads on the methane yield

The influence of temperatures and feed loads on the methane yield is shown in Figure 1. Regardless of the temperature, increasing the feed load from 2.0 to $3.0 \mathrm{~kg} \mathrm{VS} / \mathrm{m}^{3} \mathrm{~d}$ increased the methane yield and after that, a gradual increase in the OLR caused a decrease in the methane yield. According to the results, total gas production reached the highest amount at $35^{\circ} \mathrm{C}$ for a loading rate of $3.0 \mathrm{kgVS} / \mathrm{m}^{3} \mathrm{~d}\left(0.12 \mathrm{~m}^{3} \mathrm{CH}_{4} / \mathrm{kgVS}\right)$ and methane yield increased $\left(43 \%\right.$ higher at $35^{\circ} \mathrm{C}$ relative to $25^{\circ} \mathrm{C}$ ) with a temperature increase from 25 to $35^{\circ} \mathrm{C}$. At $35^{\circ} \mathrm{C}$, ultimate methane yield of $0.061,0.12$ and $0.02 \mathrm{~m}^{3} \mathrm{CH}_{4} / \mathrm{kg}$ VS were obtained at 2.0, 3.0 and $4.0 \mathrm{kgVS} / \mathrm{m}^{3} \mathrm{~d}$, respectively.

\section{Effect of temperatures and feed loads on biogas composition}

One of the main objectives of this research was to determine production and composition of biogas during anaerobic process at different loading rates and temperatures. The biogas production at steady-state condition was found to be $44.8,36$ and $26 \mathrm{~L} / \mathrm{d}$ at a load of $3.0 \mathrm{~kg} \mathrm{VS} / \mathrm{m}^{3} \mathrm{~d}$ at 35 , 30 and $25^{\circ} \mathrm{C}$, respectively. Further increase of the feeding rate up to $4.0 \mathrm{~kg} \mathrm{VS} / \mathrm{m}^{3} \mathrm{~d}$ resulted in decreases in biogas production rates. The variation of methane production is shown in Figure 2. The maximum methane contents $(70.2 \%)$ were calculated at a load of $3.0 \mathrm{~kg} \mathrm{VS} / \mathrm{m}^{3} \mathrm{~d}$ $\left(35^{\circ} \mathrm{C}\right)$ and the minimum $(30 \%)$ was at a load of $4.0 \mathrm{~kg}$ $\mathrm{VS} / \mathrm{m}^{3} \mathrm{~d}\left(25^{\circ} \mathrm{C}\right)$.

\section{Effect of temperatures and feed loads on COD} accumulation

Population of anaerobic microorganisms and their adaptation to the new environmental conditions typically take a significant period of time to establish themselves to be fully effective. According to Figure 3, a small quantity of methane production at the first load allowed for accumulation of soluble COD up to $3010 \mathrm{mg} / \mathrm{L}$ at $2.5 \mathrm{~kg}$ $\mathrm{VS} / \mathrm{m}^{3} \mathrm{~d}$ and ascending rates of methane production were observed. After a gradual increase of OLR up to $3.0 \mathrm{~kg} \mathrm{VS} / \mathrm{m}^{3} \mathrm{~d}$, methane production increased up to 31.4 L/d and COD reached $3200 \mathrm{mg} / \mathrm{L}$. VS removal was calculated $72 \%$ at this load but it decreased at other loads. In the next loads of 3.5 and $4.0 \mathrm{~kg} \mathrm{VS} / \mathrm{m}^{3} \mathrm{~d}$ COD increased up to 3800 and $4900 \mathrm{mg} / \mathrm{L}$, respectively (at $\mathrm{pH}=7.5$ and 7.1, free ammonia concentration 240 and $261 \mathrm{mg} / \mathrm{L})$. The process appeared inhibited and/or overloaded by the accumulation of volatile fatty acids that lead methanogens to be inactive. The results at 30 and $35^{\circ} \mathrm{C}$ were similar.

\section{Effect of temperatures and feed loads on $\mathrm{pH}$}

The $\mathrm{pH}$ variation at $35^{\circ} \mathrm{C}$ is shown in Figure 4. The $\mathrm{pH}$ stabilized between $6.8 \pm 0.1$ and $7.8 \pm 0.1$ in all runs. Hence the $\mathrm{pH}$, which did not vary significantly among different loads, was in the optimum range for methanogens in all treatments. Total $\mathrm{NH}_{3}-\mathrm{N}$ within each load did not vary a lot, and ranged from 68 to $256 \mathrm{mg} / \mathrm{L}$ (Figure 4).

\section{Discussion}

\section{Effect of temperatures and feed loads on the methane} yield

The loading rate and temperature are obviously critical process parameters in anaerobic treatment. The influence of temperature and feed loads on the methane yield have been shown in Figure 1. These findings are in agreement with the results of Alvarez et al. [15]. They reported that there was a linear relationship between methane yield and loading rate at lower loading rates. The maximum methane yield was observed at $35^{\circ} \mathrm{C}$

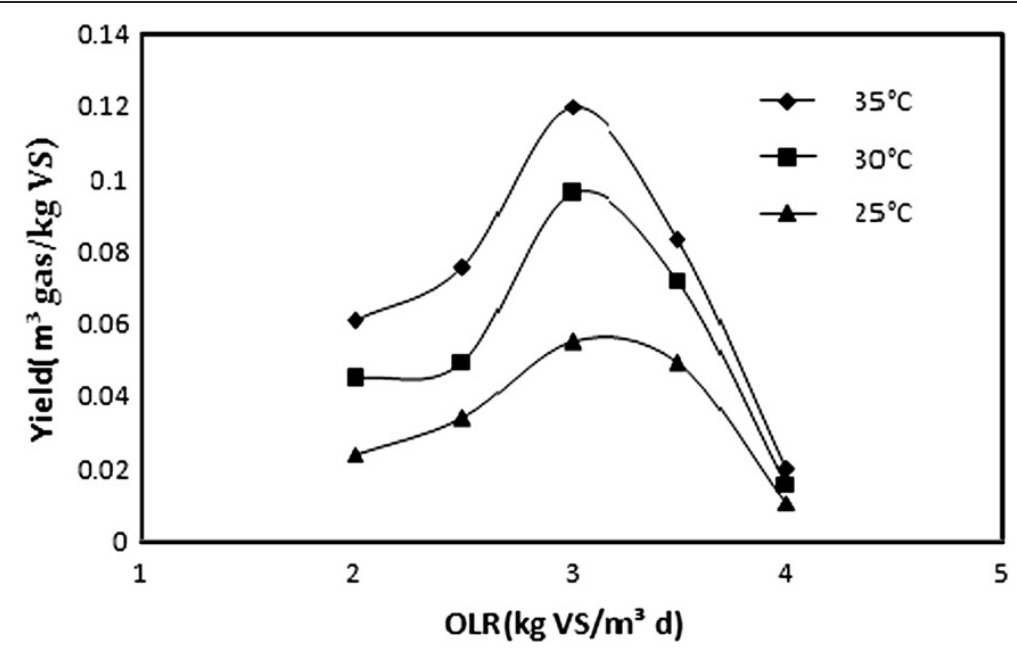

Figure 1 Methane yield of different loads and temperatures. 


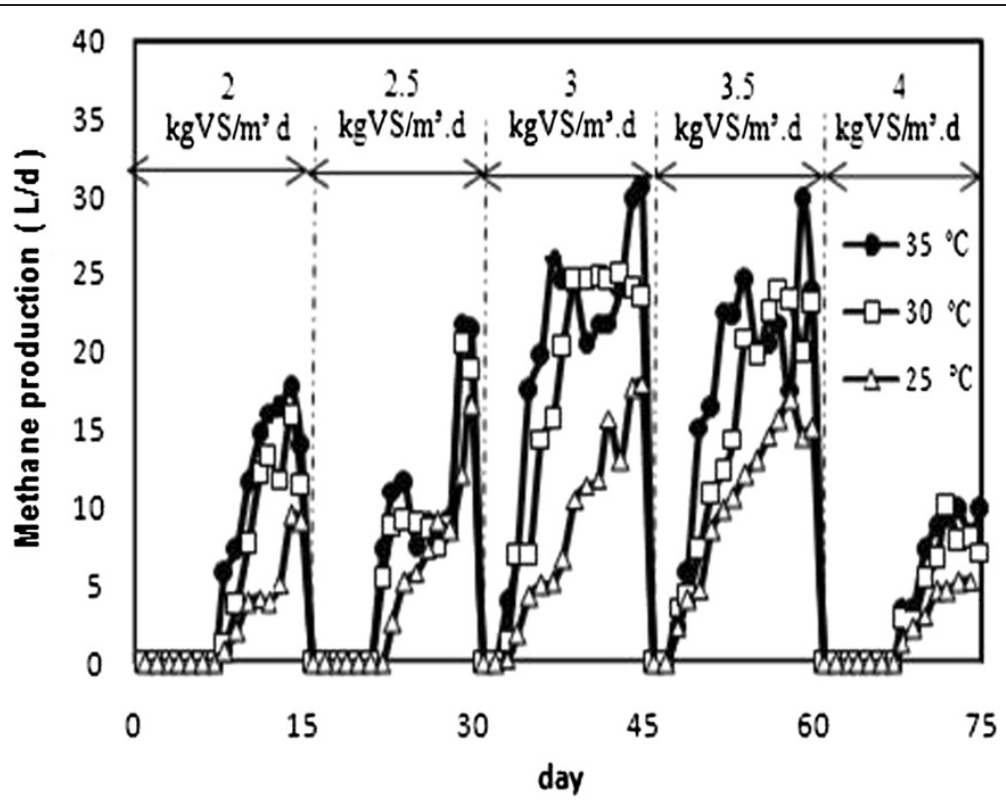

Figure 2 Variation of methane production in different loads and temperatures.

(0.12 $\left.\mathrm{m}^{3} \mathrm{CH}_{4} / \mathrm{kgVS}\right)$ because of the suitable type and composition of substrate, microbial composition and temperature. At intermediate loading rates, methane yield was almost constant up to a certain loading at which it starts to decrease. This breakpoint indicates the beginning of biological stress and beyond this point, the methane production rate decreased sharply. At $30^{\circ} \mathrm{C}$, the yield was $0.045,0.096$ and $0.0157 \mathrm{~m}^{3} \mathrm{CH}_{4} / \mathrm{kgVS}$ for loads of $2.0,3.0$ and $4.0 \mathrm{~kg} \mathrm{VS} / \mathrm{m}^{3} \mathrm{~d}$, respectively that was lower than the yields at $35^{\circ} \mathrm{C}$. Callaghan et al. [11] have reported the methane yield of $0.23 \mathrm{~m}^{3} / \mathrm{kgVS}$ and $50 \% \mathrm{VS}$ reduction by using a co-digestion system of fruit and vegetable waste (FVW) and Chicken manure with HRT of 21 days at $35^{\circ} \mathrm{C}$. According to Salminen et al. [16], the potential methane yield of solid poultry slaughterhouse waste and HRT of $50-100$ days at $31^{\circ} \mathrm{C}$ is high, from 0.52 to $0.55 \mathrm{~m}^{3} / \mathrm{kg}$ VS. The treatment of wastewaters containing high levels of TS or indigestion components, such as slaughterhouse wastewater or straw, will require a longer reaction period for complete degradation of particles, especially at lower temperatures. It is the most important reason of low methane yield in this case study compared with the others' results. Design parameters and related data are presented in Table 2.

\section{Effect of temperatures and feed loads on biogas composition}

Decreases in the methane content indicated hydraulic and organic overload and insufficient buffering capacity in the digester that they led to a reduction in the methanogenic

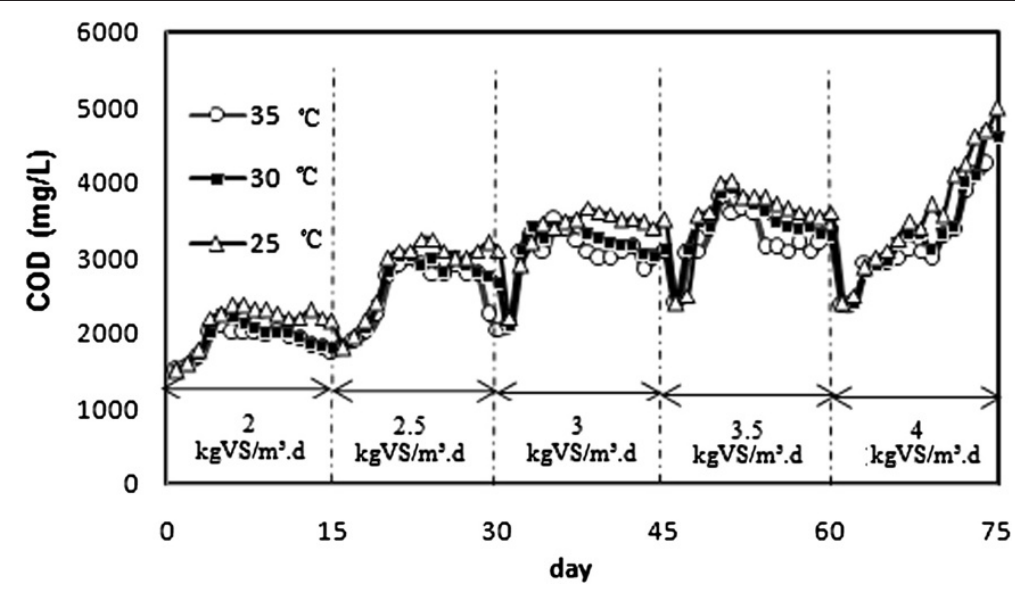

Figure 3 Variation of COD in different loads and temperatures. 


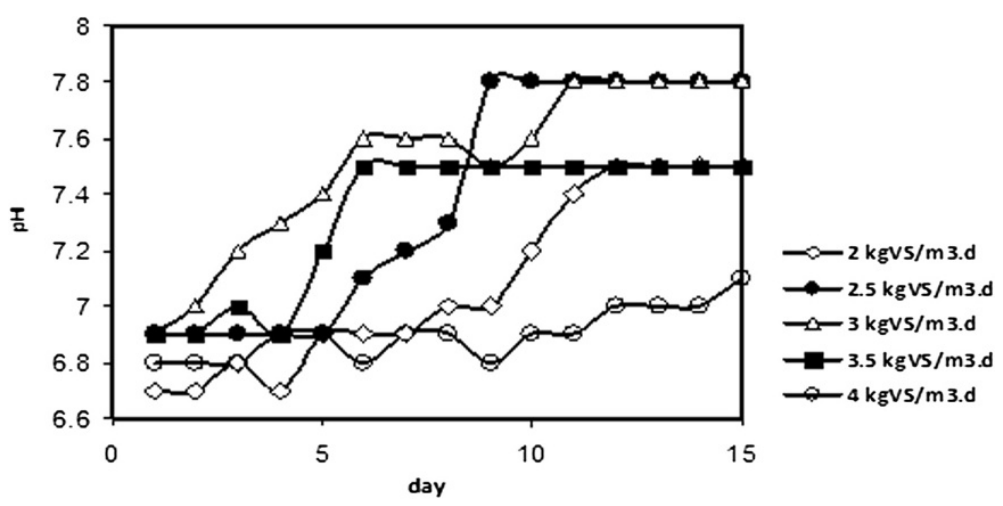

Figure 4 The variation of $\mathrm{pH}$ at $35^{\circ} \mathrm{C}$.

activity. Chae et al. [17] reported that the biogas composition differed according to digestion temperature. Methane contents in the biogas were $65.3 \%, 64.0 \%$ and $62.0 \%$ at $35^{\circ} \mathrm{C}, 30^{\circ} \mathrm{C}$ and $25^{\circ} \mathrm{C}$, respectively.

\section{Effect of temperatures and feed loads on COD accumulation}

Decrease in the temperature had a negative effect on the metabolic rate of the microorganisms. For this reason, at $25^{\circ} \mathrm{C} \mathrm{COD} \mathrm{increased} \mathrm{sharply.} \mathrm{Once} 5100 \mathrm{mg} / \mathrm{L}$, was reached, methane production decreased by $40 \%$ and VS removal dropped to $39 \%$. In fact, the effect of temperature on organic removal rate did not seem to be uniform over the whole temperature spectrum. Chae et al. [17] reported that the digestion yield at a temperature of $25^{\circ} \mathrm{C}$ showed $82.6 \%$ of that at $35^{\circ} \mathrm{C}$. These results were in agreement with previous results that showed an improvement in the biogas yields with increasing temperatures [18].

\section{Effect of temperatures and feed loads on $\mathrm{pH}$}

The $\mathrm{pH}$ stabilized between $6.8 \pm 0.1$ and $7.8 \pm 0.1$ in all runs. Both total and free ammonia concentration varied a bit between stages. A wide range of inhibiting ammonia concentrations has been reported in the papers the amount of ammonia in the digester may also affect the production of hydrogen and removal of volatile solids. Total biogas production was unaffected by small increases in ammonia nitrogen while higher increases reduced the biogas production by $50 \%$ of the original rate. In the fluidized-bed anaerobic digester, the methane formation decreased at ammonium concentrations of greater than $6000 \mathrm{mg}$ $\mathrm{NH} 4-\mathrm{N} / \mathrm{L}$. It was reported that methanogenic activity is decreased by $10 \%$ at ammonium concentrations of $1670-3720 \mathrm{mg}$ NH4-N/L, while by $50 \%$ at $4090-5550 \mathrm{mg}$ NH4-N/L, and completely zero at 5880-6000 mg NH4-N/L [19].

The free $\mathrm{NH}_{3} \pm \mathrm{N}$ concentrations calculated in this study were far below those reported as inhibitory because of a) dilution of digester content with water and b) adjustment of feed $\mathrm{C} / \mathrm{N}$ ratio. It should also be noted that both methanogenic and acidogenic microorganisms have their optimal pH. There is a considerable potential of biogas production from anaerobic digestion of poultry manure that offers several environmental, agricultural

Table 2 Average characteristics of mixture of poultry manure and straw and the effluents

\begin{tabular}{|c|c|c|c|c|c|c|c|c|c|c|c|c|c|c|c|c|c|c|}
\hline \multirow{4}{*}{$\begin{array}{l}\text { Parameter } \\
\text { (in } \mathrm{mg} / \text { except } \mathrm{pH} \& \mathrm{C} / \mathrm{N}) \\
\text { OLR }\left(\mathrm{kgVs} / \mathrm{m}^{2} \mathrm{~d}\right)\end{array}$} & \multicolumn{18}{|c|}{ Operating temperation (c) } \\
\hline & \multicolumn{6}{|c|}{35} & \multicolumn{6}{|c|}{30} & \multicolumn{6}{|c|}{24} \\
\hline & \multicolumn{2}{|c|}{2} & \multicolumn{2}{|c|}{3} & \multicolumn{2}{|c|}{4} & \multicolumn{2}{|c|}{2} & \multicolumn{2}{|c|}{3} & \multicolumn{2}{|c|}{4} & \multicolumn{2}{|c|}{2} & \multicolumn{2}{|c|}{3} & \multicolumn{2}{|c|}{4} \\
\hline & Inf & Eff & Inf & Eff & Inf & Eff & $\operatorname{lnf}$ & Eff & $\operatorname{lnf}$ & Eff & Inf & Eff & Inf & Eff & Inf & Eff & $\operatorname{lnf}$ & Eff \\
\hline COD & 1185 & 1710 & 1783 & 3200 & 2360 & 4900 & 1185 & 1780 & 1783 & 3140 & 2360 & 5000 & 1185 & 2110 & 1783 & 3300 & 2360 & 5100 \\
\hline TS & 2275 & 1153 & 3408 & 1482 & 4550 & 2616 & 2275 & 1100 & 3408 & 2010 & 4550 & 2010 & 2275 & 2000 & 3408 & 2700 & 4550 & 4020 \\
\hline VS & 2000 & 750 & 300 & 840 & 4000 & 2290 & 2000 & 863 & 3000 & 900 & 4000 & 2400 & 2000 & 1048 & 3000 & 1170 & 4000 & 2440 \\
\hline Total nitrogen & $N D^{a}$ & 256 & ND & 240 & ND & 261 & ND & 192 & ND & 180 & ND & 235 & ND & 160 & ND & 68 & ND & 105 \\
\hline $\mathrm{pH}$ & ND & 7.5 & ND & 7.8 & ND & 7.5 & ND & 7.8 & ND & 7.8 & ND & 7.8 & ND & 7.0 & ND & 6.8 & ND & 6.7 \\
\hline Alkalinity & ND & 2100 & ND & 2980 & ND & 3000 & ND & 2200 & ND & 2100 & ND & 3200 & ND & 3800 & ND & 4000 & ND & 4000 \\
\hline $\mathrm{C} / \mathrm{N}$ & 23.09 & & 23.7 & & 23.4 & & & & & & & & & & & & & \\
\hline
\end{tabular}


and socio-economic benefits throughout biogas production as a clean and renewable fuel. The process worked well with a loading of $3.0 \mathrm{kgVS} / \mathrm{m}^{3} \mathrm{~d}$ VS removal amounted $72 \%$. The temperature had an influence on the ultimate methane yield, as well as the methane contents. The highest temperature caused the most methane yield $\left(0.12 \mathrm{~m}^{3} / \mathrm{kg} \mathrm{VS}\right)$; however, the yield did not linearly increase with increasing temperature. More amount of methane yield may be achieved by extension of the hydraulic residence time because of the high levels of TS in waste.

\section{Conclusion}

The study clearly indicates that anaerobic digestion is one of the most effective biological processes to treat a wide variety of solid organic waste products. The prime advantages of this technology include (i) organic wastes with a low nutrient content can be degraded by codigesting with different substrates in the anaerobic bioreactors, and (ii) the process simultaneously leads to low cost production of biogas, which could be vital for meeting future energy-needs. However, different factors such as substrate and co-substrate composition and quality, environmental factors (temperature, $\mathrm{pH}$, organic loading rate), and microbial dynamics contribute to the efficiency of the anaerobic digestion process, and must be optimized to achieve maximum benefit from this technology in terms of both energy production and organic waste management. This technology has tremendous application in the future for sustainability of both environment and agriculture, with the production of energy as an extra benefit.

\section{Competing interests}

The authors declare that they have no competing interests.

\section{Authors' contributions}

$A B$ participated in the conception of the study, interpretation of data and in the given final approval of the version to be published; JSH supervised the study in all steps (acquisition, analysis, and interpretation of data); AR participated in the acquisition, analysis, and interpretation of data and helped to draft the manuscript. All authors read and approved the final manuscript.

\section{Acknowledgment}

The authors would like to thank the Department of Chemical Engineering, Sharif University of Technology, for their providing help in the labs.

\section{Author details}

${ }^{1}$ University of Sharif, Tehran, Iran. ${ }^{2}$ Azad University of Tehran, Tehran, Iran.

Received: 7 May 2013 Accepted: 29 May 2013

Published: 3 July 2013

\section{References}

1. Oleskowicz-Popiel P, Seadi TA, Holm-Nielsen JB: The future of anaerobic digestion and biogas utilization. Bioresour Technol 2009, 100:5478-5484.

2. Steinfeld H, Gerber P, Wasenaar T, Castel V, Rosales M, de Haan C: Livestock's long shadow. Food and Agriculture Organization (FAO) of United Nations: Environmental issues and Options; 2006
3. Ojolo SJ, Oke SA, Animasahun K, Adesuyi BK: Utilization of poultry, cow and kitchen wastes for biogas production: comparative analyses. Iranian Journal of Environmental Health Science Engineering 2007, 4(Suppl 4):223-228.

4. Ojolo SJ, Bamgboye Al, Ogunsina BS, Oke SA: Analytical approach for predicting biogas generation in a municipal solid waste anaerobic digester. Iranian Journal of Environmental Health Science Engineering 2008, 5(Suppl 3):179-186.

5. Sommer SG, Moller HB, Petersen SO: Reduction in methane and nitrous oxide emission from animal slurry trough anaerobic digestion. In Proceedings of the Third International Symposium, Maastricht, Netherlands: Millpress Science Publisher; 2002:475-480.

6. Takdastan A, Movahedian H, Jafarzadeh N, Bina B: The Efficiency of Anaerobic Digesters on Microbial Quality of Sludge in Isfahan and Shahinshahr Waterwaste Treatment Plant. Iranian Journal of Environmental Health Science Engineering 2005, 2(Suppl 1):56-59.

7. Khalid A, Arshad M, Anjum M, Mahmood T, Dawson L: The anaerobic digestion of solid organic waste. Waste Manag 2011, 31:1737-1744.

8. Zeeman G, Wiegant WM, Koster-Treffers ME, Lettinga G: The influence of the total ammonia concentration on the thermophilicdigestion of cow manure. Agricultural Wastes 1985, 14:19-35.

9. Strik DPBTB, Domnanovich AM, Holubar PA: A pH-based control of ammonia in biogas during anaerobic digestion of artificial pig manure and maize silage. Process Biochem 2006, 41:1235-1238.

10. Calli B, Mertoglu B, Inanc B, Yenigun O: Effects of high free ammonia concentrations on the performances of anaerobic bioreactors. Process Biochem 2005, 40:1285-1292.

11. Callaghan FJ, Wase DA, Thayanithy K, Forster CF: Continuous Co-digestion of cattle slurry with fruit and vegetable wastes and chicken manure. Journal of Biomass \& Bioenergy 2002, 27:71-77.

12. Molnar L, Bartha I: High solids anaerobic fermentation for biogas and compost production. Biomass 1998, 16:173-182.

13. Johnston PH, Adams TT, Magbanua J: Anaerobic co-digestion of hog and poultry waste. Bioresour Technol 2001, 76:165-168.

14. APHA: Standard methods for the examination of water and wastewater. 20th edition. Washington, DC: American Public Health Assoc; 1998.

15. Alvarez R, Liden G: Semi-continuous co-digestion of solid slaughterhouse waste, manure, fruit and vegetable wastes. Renew Energy 2008, 33:726-734.

16. Salminen EA, Rintala J: Semi-continuous anaerobic digestion of solid poultry slaughterhouse waste: Effect of hydraulic retention time and loading. Water Res 2002, 36:3175-3182.

17. Chae KJ, Jang A, Kim IS, Yim SK: The effect of digestion temperature and temperature shock on the biogas yields from the mesophilic anaerobic digestion of swine manure. Bioresour Technol 2008, 99:1-6.

18. Masse DI, Masse L: The effect of temperature on slaughterhouse wastewater treatment in anaerobic sequencing batch reactors. Bioresour Technol 2001, 76:91-98.

19. Sawayama S, Tada C, Tsukahara K, Yagishita T: Effect of ammonium addition on methanogenic community in a fluidized bed anaerobic digestion. Journal of Bioscience Bioenergy 2004, 97:65-70.

doi:10.1186/2052-336X-11-15

Cite this article as: Babaee et al: Anaerobic slurry co-digestion of poultry manure and straw: effect of organic loading and temperature. Journal of Environmental Health Sciences \& Engineering 2013 11:15.

\section{Submit your next manuscript to BioMed Central and take full advantage of:}

- Convenient online submission

- Thorough peer review

- No space constraints or color figure charges

- Immediate publication on acceptance

- Inclusion in PubMed, CAS, Scopus and Google Scholar

- Research which is freely available for redistribution 